\title{
Diversity of Tree Species Used in Wood Carving and the Impact of Their Use on Forest Conservation in Benin.
}

Hubert O. Dossou-Yovo ( $\nabla$ dohuoly@yahoo.fr)

Laboratory of Applied Ecology, University of Abomey-Calavi, Benin

Valentin Kindomihou

Laboratory of Applied Ecology, University of Abomey-Calavi, Benin

Brice Sinsin

Laboratory of Applied Ecology, University of Abomey-Calavi, Benin

\section{Research Article}

Keywords: Fragmentation, Reforestation, Use Value, Wood Carving.

Posted Date: September 11th, 2020

DOI: https://doi.org/10.21203/rs.3.rs-75014/v1

License: (1) This work is licensed under a Creative Commons Attribution 4.0 International License.

Read Full License 


\section{Abstract}

This research aimed at assessing the diversity of timber species used in wood carving in southern Benin, impact of this activity on forest conservation, and carvers' willingness to contribute to species conservation. A preliminary survey was conducted to determine the number of wood carvers in three districts of Southern Benin. Then, a semi-structured questionnaire served to collect data from twelve wood carvers. Twenty-two species were used in wood carving with most species having red or yellow wood. The purchase of wood in industrial markets was the predominant source followed by the direct purchase from plantation and tree owners. Diospyros mespiliformis, Chlorophora excelsa,Tectona grandis and Gmelina arborea were species of which woods were most However, Gmelina arborea and Chlorophora excelsa exhibited the highest Use Value meaning their relative importance in terms of diversity of uses. All carvers reported the scarcity of woods and the destruction of forests and plantations for logging were the main cause; $25 \%$ of them own plantations of G. arborea and A. auriculiformis. Carvers indicated their willingness to have plantations of T. grandis and G. arborea for personal use and trade. Promoting reforestation and timber species plantation through sustainable tools is needed, and sensitizing them about forest conservation.

\section{Introduction}

Forests play a key role in people's life and are of inestimable value. Forests are vital natural resources (WWF, 2020) and crucial for the achievement of the Sustainable Development Goals (SDGs) (Simeons, 2018). Forests and their derivative timber and non-timber products have been used by societies around the world for thousands of years (Ramage et al., 2017), and also provide ecological services, contributing significantly to environmental stability (Simeons, 2018). Forests are also a treasury of medicinal plants and pharmaceutical ingredients (Dossou-Yovo et al., 2014, 2017). Wood harvested from natural forests and plantations is used for fuel, construction, and craft uses such as carving. Although timber and nontimber forest products remain an important source of livelihoods in large parts of the world, especially in Africa, their extraction is also a major driver of deforestation (UCS, 2016).

Wood carving has been a common cultural practice of civilizations throughout the ages. For instance, samples of wooden art bythe ancient Egyptians,Greeks, Romans and Chinese still exist. Wood carving plays a great role in the cultural identity of countries. In Benin, wood carving has been practised since time immemorial and many ancient wooden artifacts have been preserved, including many that explain the key role played by the country during the slavery period. Despite the cultural and historic importance of wood carving in Benin, no research has been conducted on this activity. Many people today still depend on wood carving for their livelihoods (Okrah, 2002; Appiah-Kubi et al., 2014; Kayode et al., 2016). As a result, much attention should be focused on this practice so as to ensure sustainable and improved 
livelihoods for wood carvers and their families. To achieve this, natural and planted forests from which wood is harvested for carving should be well managed and conserved. The aim of this paper was toreport the diversity of timber species used in wood carving in Benin, the sources of wood used, and the relative importance of the most commonly used woods. From the perspective of sustainable forest conservation, the availability of wood to carvers and their willingness to contribute to species conservation were assessed. It was expected that the results of this study wouldenable forestry advisers and political leaders to better organize wood carving throughout the country.

\section{Materials And Methods}

Prior to data collection, a preliminarysurvey was conducted to record the total number of wood carvers in three districts of Benin, Ouidah, Abomey-Calavi and Cotonou. There werefivewood carvers in Ouidah, twoin Abomey-Calavi and five in Cotonou, based at the Benin artpromotion centers. These twelve wood carvers were interviewed using a semi-structured questionnaire to gather knowledge on the diversity of woods they used, their sources of wood, the ranking of the most used woods, and categories of art made with each wood. The availability of wood in recent years as well carvers' willingness tocontribute to timber species conservation were also investigated. Based onthe local names of recorded species, de Souza (1988) and Arbonnier (2002)were used to determine the botanical name of each species. Direct observations were also made of the woods that carversusedand the products made. In order to access the relative importance of the four most usedwoods, their Use Value (Zenderland et al., 2019) was calculated by dividing the number of uses for the concerned wood by the numberof carvers who mentioned the wood as most used. Carvers were also asked to free list the causes of wood scarcity or abundance in the recent years.

\section{Results}

\section{Diversity of woody species used in carving}

The wood of 22 species, belonging to 22 genera in 15 botanical families,were reported to be used in carving. The most represented family was the Caesalpiniaceae, represented by one species in each of three genera, Afzelia africana, Delonix regia and Daniellia oliveri (Table 1). The families Moraceae, Meliaceae, Verbenaceae, Mimosaceae and Anacardiace were each represented by two species, and there was one species in each of the remaining nine families. The wood used in carving exhibited a range of colours according to the respondents (Table 1). Four major colours were recorded, yellow (seven species including two described as clear yellow and yellow brown, respectively), red (seven species), white (six species including one described as ash) and black (two species).

\section{Sources wood used in carving}

Carvers reported four sources of woods used in carving. These were wood provided by customers themselves, wood bought by carvers in industrial or local informal markets, wood purchased by carvers from owners of plantations or individual trees, and the harvest of wood from carvers' own plantations. 
The predominant source recorded was the purchase of wood in industrial wood markets $(75 \%$ of respondents), followed by the direct purchase from plantation or tree owners ( $58 \%$ of respondents), the provision of wood by customers themselves (58\% of respondents), and collection of wood from carvers' plantations ( $25 \%$ of respondents). It is important to highlight the low proportion ofcarverswho harvest wood from their own plantations.

\section{Ranking of woods used for carving}

Fifty percent of respondents reported wood of Diospyrosmespiliformis (locally called ébène in Fon; black wood) as the most used for carving while $42 \%$ mentioned the wood of Chlorophoraexcelsa (locally called lokotin; yellow brown wood) as the most used (Table 2).Wood of Tectonagrandis (têkitin in Fon; yellow wood) ranked third in this paper because it was mentioned by $50 \%$ of respondents as second most used. The fourth most used wood was Gmelinaarborea (mélina or fôfitin in Fon; white wood). Regarding the sources of the most used woods, all informants mentionedthe purchase of $D$. mespiliformis wood in industrial wood markets, wood coming from northern Benin.Some informants(25\%) reported the purchase of the wood of $C$. excelsa from tree ownersand $17 \%$ of them insisted on its provision by customers themselves. Informants who mentioned T.grandis and G.arborea confirmed that they mostly purchased wood from tree and plantation owners as well as local informal markets.

\section{The Use Value of the most used woods}

In terms of utilization, the woods of D. mespiliformis, C. excelsa, T. grandis and G. arboreawere all used for small and large ornamental arts. Additionally, the wood of $C$. excelsawas used to carve spiritual objects, and the woods of $T$. grandis and G. arboreawere used to make table utensils. Among the most commonly used species, $C$. excelsa exhibited a relatively greaterimportance than $D$. mespiliformisas shown by the Use Value (Table 3). Although the wood of G.arboreawas the fourth most commonly used, it hadthe highestUse Valuewhilewood of $D$. mespiliformis had the lowest Use Value.

\section{Availability of woods according to carvers}

All informants reported the scarcity of woods for carving in recent years. They also highlighted that wood has consequently become very expensive. With regards to the causes of this scarcity, six reasons were reported (Table 4). The most frequently mentioned cause of scarcity was thedestruction of forests and plantations for logging. The international trade of wood as well as political restrictions towards local trade of wood ranked second in the same proportion followed the exploitation of wood for charcoalproduction, population growth and lack of plantation.

\section{Willingness to contribute to recordedspecies conservation}

Only $25 \%$ of wood carvers owned plantations of G. arborea and Acacia auriculiformis, with an average area of 2.5 ha. All informants were interested in investing in woody species plantationsif they had more money. Fifty percent of carversreported that they would plant $G$. arborea while $42 \%$ would prefer to plant T. grandis plantations from which they could harvest woods for carving.

\section{Discussion}




\section{Diversity of woody species used in curving}

Twenty-three plant species were recorded as used in carving confirming that wood carvers have an extensive knowledge about the quality of woods and their utilization. The range of species used suggests that their exploitation can increase environmental pressure,contributing to forest fragmentation and local species loss all over the country. Trees are, most of the time, uprooted for wood collection so, although wood carving provides anincome to workers, it constitutes a threat to species conservation. Wood carving was reported as a threat to forest diversity in Ghana because of exploitation of endangered species (Okrah,2002). Kayode et al. (2016) recorded 39 plant species belonging to 23 families used in carving in Nigeria. Similarly, the wood carving industry in Kenya is highly dependent on indigenous tree species (Mutinda, 2014).

\section{Types of woods recorded}

The diversity of type of wood used confirms that the choice depends on items to be carved (Kayode et al., 2016). Woods, in addition to their colour also vary from soft to hard and this influences the items for which they are used. A relatively high number of species was recorded as giving red wood followed by species having yellow wood. This confirms the various attractive aspects searched for in wood by carvers and the assertion that the components of art include colour, patterns and the reproduction of visual likeness (Morris-Kay, 2010).

\section{Sources of recorded woody species}

The purchase of wood in industrial markets was recorded as the main source for carversfollowed by direct purchase from plantation and tree owners. A very low proportion of carvers ownedtheir own plantations from which woods may be collected. These aspects confirm that harvesting of wood for carving threatens the conservation of forests throughout Benin. The majority of wood traded in industrial markets comes from the central and northern parts of the country. So, natural forests and sometimesplantations are cut down to satisfy a growing demand forwood. Even customers who provided their own woods for carving are destroying individual trees that are expected to protect theenvironment. No informant mentioned the purchase of wood from public plantations meaning a lack of public forestry areas, plantations or agroforestry parks, wherein carvers couldget woods whenever they want provided they are able toafford its cost.

\section{Ranking of woods used for carving}

Diospyros mespiliformis ranked as the most used wood and informants who selected it were mostly those working in Cotonou. Carvers insisted that this wood is the most appreciated by tourists. The black colour may attract people and it is easy to sell art made with this wood even if the customers are local. Carvers using this wood targeted the international market by exporting their arts. The genus Diospyros is widely recognized for its black wood. Furthermore, informants highlightedits durability, hardness and ability to take a high polish. The collection of $D$. mespiliformis wood from natural forests to satisfy the 
increasing demand is clearly a threat to the species conservation. Chlorophora excelsa is widely used in Benin as its wood serves to make sacred objects in addition to ornamental art. Similarly to the present findings, Okonkwo et al. (2016) reported the use of C. excelsa (Iroko) in carving sacred objects in Nigeria. In addition to the exploitation of this species in carving, it is widelyused in carpentry and as medicine in Benin (Ouinsavi et al., 2005). Several years ago, the pressure placed on populations of $C$. excelsaof its exploitation in Benin was stated (Sokpon et al., 2003) and its exploitation in carving no doubt increases its extinction rate. Alternativesshould be found to help carversmaintain their livelihoods without compromising the sustainability of the species. Tectona grandis and G. arborea are two plantation species that have been grown in Benin fordecades. They were recorded among the most used in carving. Similarly to the present findings, T. grandis has also been reported in wood carving in Ghana (AppiahKubi et al., 2014). Tectona grandis and G.arborea woods were purchased from tree and plantation owners which confirms a high pressure on these species as they are also highly demanded forcarpentry throughout the country. Carvers justified the use of G.arborea wood by the fact that its white colour gave an attractive aspect for arts.In addition, they argued that woods of G.arborea and $T$. grandisaresometimesmore availablethan other woods. Similarly, G.arborea and T.grandis were mostly preferred forwood carving in India (Sharma et al., 2013). Tectona grandis has been identified as the species with most potential for the establishment ofhigh-quality tropical hardwood plantationsunder sustainable forest management (Thulasidas and Baillères, 2017)

\section{The Use Value of the most used woods}

The results confirmed that the frequency of use of a species wood can sometimes contrast with its relative importance. Gmelina arborea and $C$. excelsa both had greater Use Value than D. mespiliformis despite the more frequent use of this species.These findings confirmed the importance of the Use Value to assess the relative importance of plant species in ethnobotanical studies.

\section{Availability of woods according to carvers}

The scarcity of woods recorded in this research confirmed the high environmental pressure placed on tree species used in carving. Forests are fragmented to satisfy wood demands for carving and many other purposes. Thishas negative impacts on biodiversity conservation all over the country. Reforestation programs taking into account woody species used in carving are necessary throughout the country. Priority species can be $C$. excelsa and $D$. mespiliformis. As $T$. grandisand $G$. arboreahavealready been grown in plantations throughout the country for manydecades,leaders are encouraged to promote these speciesin plantations. It has been stated that, in Benin, farmers specialized in pole-wood production to supply urban demand for cheap construction timber (Aoudji et al., 2014). Largeindividual trees of $T$. grandis and $G$. arborea are needed to ensure a long-term wood carving activity in Benin because art made by carvers plays a great role in tourism and in the cultural identity of the country.

\section{Willingness to contribute to recorded species conservation}


Only a small proportion of wood carvers had their own plantations which confirmed that the wood supply for this activity contributes to the fragmentation of natural forests and existing plantations throughout the country. All carvers confirmed their willingness to establishplantationsif it was economically possible,and the majority of them would prefer plantations of G. arborea and T. grandis. They argued that G. arborea is a rapid growth species that can produce wood for sale and personal use in a short period of time and T. grandis,according to carvers, is a resistant and good quality wood. They also mentioned the trade of $T$. grandis wood for income generation as the species is highly demanded in carpentry in Benin and more widely in region.Similarly to the present findings, carvers in Ghana indicated their willingness to use any type of wood provided the tools and equipment for processing them work well (Appiah-Kubi et al., 2014). The present findings also confirmed the results of McEwan et al. (2020) who stated that the factors influencing the form of plantation include the type and nature of the plantation owner, and the change in demand for different and new forest products.Forestry advisers and political leaders needto takesuchfindings into account to promote plantations and ensure a sustainable wood carving industry throughout the country.In addition, carvers should be provided with tools for plantation management.

\section{Conclusion}

Many skilled artisans in Benin depend upon wood carving for their livelihoods. A diversity of species are used in carving in Southern Benin, the most used species being D. mespiliformis, C. excelsa, T. grandis and G. arborea. Gmelinaarborea and C. excelsahad the highest Use Value. Wood carving impacts on forest fragmentation and there is a need to promote reforestation and plantation, and to provide carvers with tools for plantation management. Carvers indicated their willingness to contribute to species plantation and conservation. Thisinvestigation on woody species used in carving in Benin is a pioneer research project that should help to stimulate further researchon this activity. For instance, further research is required on the financial aspects of wood carving,and the assessment of the ecological and dendrometric characteristics of the most used species in carving in order to better monitor the impacts of this activity.

\section{Declarations}

\section{Acknowledgments}

Authors are grateful to Professor Phil Harris from University of Coventry (United Kingdom) who edited the first draft of this paper. Thanks are also due to all carvers who participated in this research.

\section{NO CONFLICT OF INTEREST}

\section{References}

1. Aoudji A K N, Adegbidi A, Ganglo J C, Lebailly P (2014). Teak, Tectonagrandis f., planting in smallholders farming systems in Southern Benin. Bois et forêts des tropiques. 319(1): 7-17. 
2. Appiah-Kubi E, Tekpetey S, Essien C (2004). Plantation grown tree species for wood carving in Ghana: Concerns of traditional wood carvers. In Parrota J A, Moser C F, Scherzer A J, Koerth N E, Lederle D R (eds). Sustaining Forests, Sustaining People: The Role of Research. XXIV IUFRO World Congress, Salt Lake City USA, p. 29.

3. Arbonnier M (2002). Trees, shrubs and lianas of West African dry zones. 573 p. CIRAD, MNHN.

4. Dossou-Yovo HO, Vodouhè FG, Sinsin B (2014). Assessment of medicinal uses of plant species found on termitaria in the Pendjari Biosphere Reserve in Benin. Journal of Medicinal Plant Research. 8:368-377.

5. Dossou-Yovo HO, Vodouhè FG, Sinsin B (2017). Ethnobotanical survey of mangrove plant species used as medicine from Ouidah to Grand-Popo districts, Southern Benin. American Journal of Ethnomedicine. 4:1-6.

6. Kayode J, Ihinmikaiye S O, Arowosegbe S, Oyedji A A (2016). Conservation of Botanicals used for Carving by the ljaw Ethnic Group of Bayelsa State, Nigeria. International Journal of Natural Resource Ecology and Management. 1(2): 58-62.

7. McEwan A, Marchi E, Spinelli R, et al. (2020). Past, present and future of industrial plantation forestry and implication on future timber harvesting technology. Journal of Forestry Research 31: 339-351.

8. Morris-Kay G M (2010). The evolution of human artistic creativity. Journal of Anatomy 216: 158-176.

9. Mutinda J (2004). Assessment of the impact of the woodcarving industry on the Environment: A study of Wamunyu Location, Mwa Disctrict, Kenya. Journal of Environment and Earth Science. 4(6): 48-64.

10. Okonkwo E E, Ukaegbu M O, Eyisi A P (2016). A documentation of Some Traditional Aspects of Wood Consumption in Anaocha, Nigeria. SAGE Open: 1-8.

11. Okrah E (2002). The Growth of Wood Carving Industry in Ghana and its Threats to Selected Tree Species. Master's Thesis. LUMES Lund University. $47 \mathrm{p}$.

12. Ouinsavi C, Sokpon N, Bada O (2004). Utilization and traditional strategies of in situ conservation of Iroko (Miliciaexcelsa C. C. Berg) in Benin. Fuel and Energy Abstracts. 207(3): 341-350.

13. Ramage $M H$, Burridge $H$, Busse-Wicher $M$, et al. (2017). The wood from the trees: The use of timber in construction. Renewable and Sustainable Energy Reviews 68: 333-359.

14. Sharma C L, Sharma M, Lipoktila (2013). Timber Species Used in Traditional Wood Carving by AO Tribe of Nagaland. Life Sciences leaflets. 4: 31-40.

15. Simoens C (2018). Plannet : 12 reasons why forests are important. Glo.be for a sustainable world. glo-be.be

16. Sokpon N, Ouinsavi C, Azonkponon N (2003). Stratégies de Gestion de l'Iroko (Miliciaexcelsa) dans I'Aire Culturelle Vodun au Bénin. XII World Forestry Congress. Québec City. Canada.

17. de Souza S (1988). Names of Plants in Benin local languages. $424 \mathrm{p}$.

18. Thulasidas P K, Baillères H (2017). Wood Quality for Advanced Uses of Teak from natural and Planted Forest. In Kollert W, Kleine M (eds). The Global Teak Study. Analysis, Evaluation and Future 
Potential of Teak Resources. IUFRO World Series Volume 36. Chapter 6. p. 73-81. ISSN 1016-3263. 19. UCS (2016). Wood products. ucsusa.org.

20. WWF (2020). These green giants are essential for people, climate and wildlife. wwf.panda.org.

21. Zenderland J, Hart R, Bussmann RW, Paniagua NY, Zambrana SS, Kikvidze Z, Kikodze D, Tchelidze D, Khutsishvili M, Batsatsashvili K (2019). The use of "Use Value": Quantifying importance in Ethnobotany. Economic Botany. 73:293-303.

\section{Tables}

Table 1. Woody species used in carving and wood colour as described by wood carvers. 


\begin{tabular}{|c|c|c|c|}
\hline Scientific name & $\begin{array}{l}\text { Local name in } \\
\text { Fon }\end{array}$ & $\begin{array}{l}\text { Botanical } \\
\text { family }\end{array}$ & $\begin{array}{l}\text { Wood } \\
\text { colour }\end{array}$ \\
\hline Acacia auriculiformis A.Cunn. ex Benth., 1842 & Acacia & Mimosaceae & Black \\
\hline Afzelia africana Sm. \& Pers., 1798 & Abzélia & Caesalpiniaceae & Red \\
\hline $\begin{array}{l}\text { Artocarpus } \\
\text { communis J.R.Forst. \& G.Forst., } 1775\end{array}$ & Blêfoutoutin & Moraceae & Yellow \\
\hline Azadirachta indica A.Juss., 1830 & Kininetin & Meliaceae & Red \\
\hline Chlorophora excelsa (Welw.) C.C.Berg, 1982 & Lokotin & Moraceae & $\begin{array}{l}\text { Yellow } \\
\text { brown }\end{array}$ \\
\hline Cocos nucifera L., 1753 & Agonkêtin & Arecaceae & Red \\
\hline Daniellia oliveri (Rolfe) Hutch. \& Dalziel, 1928 & Zatin & Caesalpinaceae & Red \\
\hline Delonixregia (Bojer ex Hook.) Raf., 1837 & Fontin & Caesalpinaceae & Ash \\
\hline $\begin{array}{l}\text { Diospyros mespiliformis Hochst. ex A.DC., } \\
1844\end{array}$ & Ebène & Ebenaceae & Black \\
\hline Eucalyptus camaldulensis Dehnh., 1832 & Ecalitus & Myrtaceae & $\begin{array}{l}\text { Clear } \\
\text { yellow }\end{array}$ \\
\hline Gardenia erubescens Stapf \& Hutch., 1909 & Dakplatin & Rubiaceae & Yellow \\
\hline Gmelina arborea Roxb. ex Sm., 1810 & Mélina & Verbenacea & White \\
\hline Khaya senegalensis (Desr.) A. Juss., 1830 & Zounza & Meliaceae & Red \\
\hline Mangifera indica L., 1753 & Amangatin & Anacardiaceae & White \\
\hline Newbouldia laevis (P. Beauv.) Seem., 1864 & Désrêguêtin & Bignoniaceae & White \\
\hline Prosopis africana (Gull. \&Perr.)Taub., 1893 & Kakêtin & Mimosaceae & Red \\
\hline Pterocarpus erinaceus Poir., 1804 & Kosso & Papilionaceae & Yellow \\
\hline Rauvolfia vomitoria Afzel., 1817 & Atêtin & Apocynaceae & White \\
\hline Spondias monbin L. 1753 & Akinkontin & Anacardiaceae & White \\
\hline Tectona grandis L.f, 1782 & Têkitin & Verbenaceae & Yellow \\
\hline Terminalia catappaL. 1767 & Kolatin & Combretaceae & Red \\
\hline $\begin{array}{l}\text { Zanthoxylum zanthoxyloides (Lam.) Zepern. \& } \\
\text { Timler, } 1981\end{array}$ & Hêtin & Rutaceae & Yellow \\
\hline
\end{tabular}

Table 2. Ranking of the species most used in carving 


\begin{tabular}{|l|c|c|}
\hline \multirow{2}{*}{ Species } & \multicolumn{2}{|c|}{ Percentage of respondents ranking the species } \\
\cline { 2 - 3 } & Most used & Second most used \\
\hline Diospyros mespiliformis Hochst. ex A.DC. & 50 & 0 \\
\hline Chlorophora excelsa (Welw.) C.C.Berg. & 42 & 0 \\
\hline Tectona grandis L. & 0 & 50 \\
\hline Khaya senegalensis (Desr.) A. Juss. & 8 & 8 \\
\hline Gmelina arborea Roxb. ex Sm. & 0 & 17 \\
\hline Acacia auriculiformis A.Cunn. ex Benth. & 0 & 8 \\
\hline Daniellia oliveri (Rolfe) Hutch. \& Dalziel & 0 & 9 \\
\hline Afzelia africana Sm. \& Pers. & 0 & 8 \\
\hline
\end{tabular}

Table 3.Use Value of the four woods most used in carving.

\begin{tabular}{|l|c|c|c|}
\hline Wood & $\begin{array}{l}\text { Number of } \\
\text { uses }\end{array}$ & $\begin{array}{l}\text { Number of informants } \\
\text { mentioning }\end{array}$ & $\begin{array}{l}\text { Use } \\
\text { Value }\end{array}$ \\
\hline $\begin{array}{l}\text { Diospyros } \\
\text { mespiliformis Hochst. ex A.DC. }\end{array}$ & 2 & 6 & 0.33 \\
\hline $\begin{array}{l}\text { Chlorophora } \\
\text { excelsa (Welw.) C.C.Berg. }\end{array}$ & 4 & 5 & 0.80 \\
\hline Tectona grandis L. & 3 & 6 & 0.50 \\
\hline Gmelina arborea Roxb. ex Sm. & 3 & 2 & 1.50 \\
\hline
\end{tabular}

Table 4. Causes of wood scarcity in recent years according to carvers

\begin{tabular}{|l|c|}
\hline Cause & Percentage of informants \\
\hline Destructions of forests and plantations for logging & 58 \\
\hline International trade of wood & 17 \\
\hline Political restrictions on local trade & 17 \\
\hline Wood exploitation for charcoal production & 8 \\
\hline Lack of plantations & 8 \\
\hline Lack of plantations & 8 \\
\hline
\end{tabular}

